\title{
Savings drive unsettles Australian science
}

Sydney. Australian researchers are facing four months of uncertainty before they know how much their research programmes will suffer as part of the new coalition government's general drive to save \$A8 billion (US\$6.7 billion) over its first two budgets. The government has already started to make big cuts in all departments, and direct funding for science and technology - as well as indirect support through universities - is coming under close scrutiny.

Eight weeks after John Howard became prime minister on the defeat of the Labor government in March's general elections, the first of three rounds aimed at reducing the size of the public service has started. About 200 staff will leave the Department of Industry, Science and Tourism by July, and nearly 1,800 will leave the Department of Employment, Education, Training and Youth Affairs which oversees universities.

But the resulting savings will not be sufficient to meet the government's target, and cuts to research programmes will also be necessary. The first indication of shrinkage in the previous government's research and development programme came when a proponent of a High Performance Computing and Communications programme revealed that the \$A30 million allocated "has already been halved and funds are evaporating fast".

Peter McGauran, the new science and technology minister, is already having talks with research organizations, which say that their concerns are being listened to. But any scientist whose research is supported by the government is urgently seeking confirmation of rumoured cuts.

McGauran confirms that pre-election promises for science and technology will be met (see Nature 380, 192; 1996). But he points out that all areas of government are being examined for savings based on "duplication or lack of priority", and that science and technology "are no different". He has not ruled out using cuts in base funding to meet earlier promises; the final results will be known when the government announces its budget plans on 20 August.

Among initiatives receiving the closest scrutiny are several only recently announced by the previous government. Seven Major National Research Facilities and three 'Innovation Flagships' announced in Labor's Innovation Statement (see Nature 378, 653; 1995) appear to have been secured with contracts. But the funding of other new programmes, such as the computing project, is vulnerable.

Also in serious doubt is a move by Australian astronomers to become paid-up participants in the world's largest optical telescope being built in Chile by the European Southern Observatory, which was supported by the former Science Minister, Peter Cook, shortly before the 2 March election

(see Nature 379, 668; 1996).

Particular fears are being expressed in universities following a bruising first meeting between the Australian Vice-Chancellors' Committee (AVCC) and Amanda Vanstone, the new Education Minister. Fay Gale, vice-chancellor of the University of

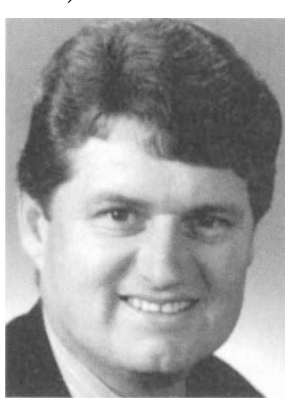

McGauran: job losses at CSIRO 'inevitable'.
Western Australia and president of the AVCC, has warned that budget reductions of 5 to 10 per cent are likely to be forced on universities, and has asked each university to specify what it would have to cut.

The AVCC, having previously welcomed the Coalition's pre-election promise to "maintain the levels of funding to universities in terms of operating grants", is now sceptical. Gale said reneging on commitments "would have a disastrous effect on university teaching and research".

The restructuring of Australia's major science agency, the Commonwealth Scientific and Industrial Research Organisation, by removing the upper echelon of six institutes (see Nature 380, 276; 1996), may help the government to direct more money to research. Resolving the continuing problems of the troubled Division of Animal Production may offer immediate savings.

Despite pressure from his rural constituency, McGauran accepts the need for "inevitable staff redundancies" in this division, and the sale of pastoral properties to reduce its crippling debt of more than \$A5 million and budget overruns due to reduced funding from the wool industry. $\mathrm{He}$ has asked for options to be presented for a "countercyclical approach" to funding the division, aimed at insulating it from the short-term fluctuations in commodity prices.

Following a rocky relationship with the previous government, CSIRO appears to have made a constructive start with the new government. "We are pleased with the active interest of both ministers in the organisation, and with their commitment to delivering the promised increase of $A \$ 20$ million per annum for three years on our existing base funding," says Adrienne Clarke, chair of the CSIRO Board.

McGauran has moved to reassure the 62 Cooperative Research Centres by affirming the government's "strong commitment to maintaining" the CRC programme, and by approving five more CRCs. However, a new committee to oversee the programme will be asked "to test the centres very rigorously against their agreed outcomes and the CRC evaluation criteria".

Peter Pockley

\section{AIDS office opposes outside planning}

Washington. Senior research managers at the US National Institutes of Health (NIH) have taken issue with the recommendation in a recent report on federally funded AIDS research, arguing that the direction of such research should remain firmly in the hands of institute directors and their advisers.

The report, issued in March, had suggested that this role should, in part, be assumed by the panels of external scientists responsible for reviewing research grants. It said that members of these panels should be involved in setting AIDS research priorities, and that the panels should judge competing applications in part on the extent to which they meet such priorities which are yet to be decided.

At present, peer review groups, or 'study sections', judge proposals strictly on scientific merit, not on the nature of the research. But the report of a panel of 118 scientists and others, led by Arnold Levine, a molecular biologist at Princeton University, New Jersey, and published in April, suggests that external review panels should be "better informed" of scientific priorities for AIDS research, and should "consider these priorities in their review".

According to William Paul, director of the NIH Office of AIDS Research, this recommendation has not met with enthusiasm among directors of NIH's 24 institutes, divisions and centres. He told a congressional subcommittee last week that there is 'universal' opposition among the directors to involving the grant-reviewing scientists in setting research priorities.

"We felt the [Levine] panel had probably not given adequate consideration" to the matter, Paul told John Porter (Republican, Illinois), the chairman of subcommittee of the House of Representatives appropriations committee that funds the NIH. "It is essential that the peer review process be removed from the planning process," Paul said. "The purpose of peer review is to make the scientific judgement as to whether or not a grant is meritorious in its own right."

Harold Varmus, the director of NIH, agrees. "This is not to say that the significance of the research is not an issue in the initial peer review process," Varmus told the same subcommittee hearing. "But to ask the peer reviewers to try to align their evaluation [with the] priorities of various institutes and the Office of AIDS Research to my mind would be a mistake."

Meredith Wadman 